Research Article

\title{
Water in maize whorl enhances the control of Spodoptera frugiperda with insecticides ${ }^{1}$
}

\author{
Adriano Bialozor ${ }^{2}$, Clérison Régis Perini², Jonas André Arnemann², Henrique Pozebon², Adriano Arrué $\mathrm{Melo}^{2}$, \\ Guilherme Padilha², Regina Sonete Stacke ${ }^{2}$, Letícia Puntel ${ }^{2}$, Lucas Drebes ${ }^{2}$, Jerson Vanderlei Carús Guedes ${ }^{2}$
}

\section{ABSTRACT}

The fall armyworm Spodoptera frugiperda is among the main insect-pests on maize crops, due to its damaging potential and control issues related to the larval habit of concealing itself within the plant whorl. This study aimed to evaluate the effect of water in the maize whorl, combined with insecticides and spray sets, on the damage caused by $S$. frugiperda and the grain yield. The experiments were carried out under field conditions, at two cropping seasons, both with $B t$-maize hybrids, in a $2 \times 2 \times 5+1$ factorial scheme, testing the presence or absence of water inside the plant whorl, two insecticides and five spray sets (combinations of spray volumes, nozzle types, pressures and spraying speed), plus a control without water and insecticide. The presence of water inside the whorl reduced the damage caused by $S$. frugiperda during the early growth stages, especially in the plants sprayed with the insecticide chlorantraniliprole. The spray sets with $200 \mathrm{~L} \mathrm{ha}^{1} / 20.3 \mathrm{psi}$ or $250 \mathrm{~L} \mathrm{ha}^{1 / 33.4}$ psi provided the highest reductions in the percentage of damaged plants and damage scores, regardless of the insecticide. Therefore, the spraying of insecticides, when there is water from irrigation, dew or rainfall inside the maize whorl, improves the control of $S$. frugiperda in maize crops, especially in $B t$-maize.

KEYWORDS: Chlorantraniliprole, chlorfenapyr, fall armyworm, pest management.

\section{INTRODUCTION}

The fall armyworm Spodoptera frugiperda (J. E. Smith) (Lepidoptera: Noctuidae) can reduce the maize grain yield up to $60 \%$, according to the sowing date, maize hybrid and plant growth stage at which the damage occurs (Cruz et al. 2008). The main control strategy for $S$. frugiperda is the use

\section{RESUMO}

Água em cartucho de milho melhora o controle de Spodoptera frugiperda com inseticidas

A lagarta do cartucho Spodoptera frugiperda é uma das principais pragas do milho, pelos danos que ocasiona e pela dificuldade de controle com as lagartas abrigadas e protegidas no interior das folhas do cartucho. Objetivou-se avaliar a influência da água no cartucho de milho, em combinação com inseticidas e conjuntos de pulverização, sobre os danos causados por $S$. frugiperda e a produtividade de grãos. Os experimentos foram conduzidos em campo, sob duas épocas de cultivo, ambas com híbridos de milho- $B t$, em esquema fatorial $2 \times 2 \times 5+1$, testando presença ou ausência de água no cartucho, dois inseticidas e cinco conjuntos de pulverização (combinações de volumes de calda, tipos de bico, pressões e velocidade de aplicação), mais um controle sem água e inseticida. A presença de água no cartucho reduziu os danos de S. frugiperda nos estádios iniciais, especialmente nas plantas tratadas com o inseticida clorantraniliprole. Os conjuntos de aplicação com $200 \mathrm{~L} \mathrm{ha}^{1} / 20,3$ psi ou $250 \mathrm{~L} \mathrm{ha}^{1 / 33,4}$ psi proporcionaram as maiores reduções no percentual de plantas atacadas e nas notas de dano, independentemente do inseticida. Portanto, a aplicação de inseticidas, quando há água no cartucho do milho procedente de irrigação, orvalho ou chuvas, melhora o controle de $S$. frugiperda em cultivos de milho, especialmente em milho-Bt.

PALAVRAS-CHAVE: Clorantraniliprole, clorfenapir, lagartado-cartucho, manejo de pragas.

of genetically modified maize plants expressing the toxins Cry or Vip (i.e., Bt-maize). However, its control has become difficult, due to the increasing occurrence of populations resistant to some $B t$ toxins (Cruz et al. 2013, Farias et al. 2014), demanding insecticide sprays in maize plants that should be highly resistant to the $S$. frugiperda attack (Burtet et al. 2017).

1. Received: July 16, 2019. Accepted: Nov. 11, 2019. Published: Apr. 08, 2020. DOI: 10.1590/1983-40632020v5059517.

2. Universidade Federal de Santa Maria, Centro de Ciências Rurais, Santa Maria, RS, Brasil.

E-mail/ORCID: a.bialozor@yahoo.com.br/0000-0001-9310-0235, periniagro@gmail.com/0000-0002-3461-2721, jonasarnemann@gmail.com/0000-0002-6100-4369, henriquepozebon@gmail.com/0000-0001-9354-5998,

adrianoarrue@hotmail.com/0000-0001-6868-4347,guilhermepadilha35@gmail.com/0000-0003-1198-9304,re_stacke@hotmail.com/ 0000-0003-1721-4331, leticia_puntel@hotmail.com/0000-0002-2562-7737, lucasdrebes@hotmail.com/0000-0001-8687-4603, jerson.guedes@gmail.com/0000-0003-0652-3083. 
The control of $S$. frugiperda in maize plants using insecticide spraying presents serious downsides related to the feeding behavior of the larvae, which migrate into the plant whorl immediately after its emergence and remain sheltered during the whole larval phase (Busato et al. 2002). The whorl is a funnel-shaped structure formed by the growing leaves of the maize plant during its early development stages (Girardin 1992, Ritchie et al. 1993). S. frugiperda larvae stay lodged inside the maize whorl while feeding and producing excrements, which partially block the entrance of the funnel and afford protection from possible predators and insecticide sprays alike (Gassen 1996).

Due to the concealed habit of the larvae, the control of $S$. frugiperda in maize plants is highly dependent on the spray volume. Silva (1999) obtained a higher larval mortality using $300 \mathrm{~L} \mathrm{ha}^{-1}$ of spray volume, when compared to $150 \mathrm{~L} \mathrm{ha}^{1}$. Higher spray volumes cause the insecticide to drip inside the whorls, increasing the chances of direct contact with the larvae (Guedes \& Maziero 2011). The addition of insecticides to sprinkler irrigation water has also been pointed out as an effective tool for pest control, due to the higher spray coverage and plant wetting resulted therein (Vieira \& Silva 2006). Nonetheless, the propensity to minimize operational costs has led maize growers to reduce spray volumes (Bayer et al. 2011), potentially jeopardizing the control efficiency of $S$. frugiperda.

Besides providing shelter for armyworm larvae, maize leaves can also store water from rain, dew or overhead irrigation, due to their spatial arrangement in the whorl (Basantaet al. 2000). It is possible that the presence of water inside the whorl enhances the control efficiency of insecticides sprayed at this moment, targeting specifically at $S$. frugiperda, but such hypothesis remains untested. Therefore, this study aimed to evaluate the effect of water inside the maize whorl (simulating a moderate rain or irrigation), combined with insecticides and spray sets, on the damage caused by $S$. frugiperda and the grain yield of maize plants.

\section{MATERIAL AND METHODS}

Two experiments were carried out under field conditions during two cropping seasons (first-crop and second-crop maize), in 2015/2016, in Santa Maria, Rio Grande do Sul state, Brazil (2943'40”S, $53^{\circ} 33^{\prime} 43^{\prime \prime} \mathrm{W}$ and $95 \mathrm{~m}$ of altitude). The climate of the region is classified as $C f a$ (i.e., humid subtropical with hot summers and without dry seasons) (Alvares et al. 2013). Both sowings were carried out with $B t$-maize hybrids: November 29, 2015, with the 30F53YH hybrid (first crop); and January 4, 2016, with the 3161 YH hybrid (second crop). The sowing density was 6.8 seeds $\mathrm{m}^{-2}$.

The choice of the maize hybrids was based on recommendations for each sowing date and the fact that both express CrylF and CrylAB toxins. Fertilization at sowing comprised $350 \mathrm{~kg} \mathrm{ha}^{-1}$ of the $05-20-20$ fertilizer $\left(\%\right.$ of $\mathrm{N}, \mathrm{P}_{2} \mathrm{O}_{5}$ and $\mathrm{K}_{2} \mathrm{O}$, respectively), followed by surface fertilization with urea $(45 \%$ of $\mathrm{N})$ at the growth stages V3 and V6 of the maize plants (Ritchie et al. 1993), at the doses of $45 \mathrm{~kg} \mathrm{ha}^{-1}$ and $22.5 \mathrm{~kg} \mathrm{ha}^{-1}$ of $\mathrm{N}$, respectively. In both experiments, weeds were controlled at 15 days prior to sowing with the spraying of 1,200 $\mathrm{g}$ a.i. $\mathrm{ha}^{-1}$ of glyphosate (Zapp Qi ${ }^{\circledR} 620 \mathrm{SL}$ ), and in postemergence at the growth stage V4 of the maize plants with $1,250+1,250 \mathrm{~g}$ a.i. ha ${ }^{-1}$ of atrazine + simazine (Primatop $^{\circledR} 250+250$ SC).

The experimental design for both trials was randomized complete blocks, with four replications, and treatments in a $2 \times 2 \times 5+1$ factorial scheme, in $2 \mathrm{~m} \times 5 \mathrm{~m}$ plots (four rows spaced $0.5 \mathrm{~m}$ per plot). The levels of treatment factors comprised the presence or absence of water inside the maize whorl (after overhead irrigation), two insecticides (chlorantraniliprole - Premio ${ }^{\circledR} 200$ SC, 24 g a.i. ha $^{-1}$; chlorfenapyr - Pirate ${ }^{\circledR} 240$ SC, 192 g a.i. ha ${ }^{-1}$ ) and five spray sets resulting from combinations of spray volumes, nozzle types, pressures and spraying speed (Table 1). An additional treatment with no irrigation or insecticide spraying comprised the control.

Infestation by $S$. frugiperda occurred naturally, and damage was monitored and quantified using the scale proposed by Davis et al. (1992), which comprises the following scores: $0=$ no damage; $1=$ less than three small injuries; $2=$ small round injuries; $3=$ rectangular injuries smaller than $1.3 \mathrm{~cm}$; $4=$ injuries between $1.3 \mathrm{~cm}$ and $2.5 \mathrm{~cm} ; 5=$ four to seven injuries bigger than $2.5 \mathrm{~cm} ; 6=$ holes beginning to appear on expanded leaves; $7=$ more than eight injuries on whorl leaves and small holes on expanded leaves; $8=$ most whorl leaves injured and holes of every size on expanded leaves; $9=$ whorl and expanded leaves virtually destroyed. Evaluations 
Table 1. Spray sets assessed with the respective spray volumes, nozzles, pressures, speeds and coverages on water-sensitive paper.

\begin{tabular}{cccccc}
\hline Spray set & Volume $\left(\mathrm{L} \mathrm{ha}^{-1}\right)$ & Nozzle (model) & Pressure $(\mathrm{psi})$ & Speed $\left(\mathrm{km} \mathrm{h}^{-1}\right)$ & Coverage \\
\hline S1 & 50 & ADGA 01 & 12.3 & 5.4 & 5.4 \\
S2 & 100 & ADGA 015 & 14.5 & 5.4 & 5.4 \\
S3 & 150 & ADGA 02 & 23.2 & & \\
S4 & 200 & ADGA 03 & 20.3 & 5.4 & \\
S5 & 250 & ADGA 03 & 33.4 & \\
\hline
\end{tabular}

were carried out every three days, beginning at the emergence of the maize plants.

Insecticides were sprayed when $20 \%$ of the plants reached damage scores $\geq 3$ (IRAC 2017). This control level was reached at the growth stage V4 of the maize plants for the first crop, and at the stage V1 for the second one. Additional sprayings were carried out fortnightly, or when the average of damaged plants surpassed $20 \%$.

Prior to the insecticide sprays, irrigation was carried out ( $4 \mathrm{~mm}$ of water depth) using impact sprinklers (model AJS-13 ${ }^{\circledR}, 0.86 \mathrm{~m}^{3} \mathrm{~h}^{-1}$ ). In the plots that needed absence of water inside the whorl, the plants were covered with a plastic canvas atop metallic arcs of $2 \mathrm{~m} \times 2 \mathrm{~m}$ (Figure 1). The insecticides were sprayed after irrigation, using a $\mathrm{CO}_{2}$-pressurized backpack sprayer. The damage caused by $S$. frugiperda on the maize plants was evaluated every three days after spraying, until the growth stage V13, by sampling twenty plants of the two central rows of each plot and employing the scale proposed by Davis et al. (1992). The grain yield was assessed in each treatment by harvesting $2.0 \mathrm{~m}^{2}$ of the central area per plot.

Data were submitted to the Shapiro-Wilk normality test, undergoing the transformation of $a \sqrt{ }(x+0.5)$. Afterwards, analysis of variance was performed, followed by mean comparisons by the Tukey test (or the Scheffé test for the mean contrasts between the control and each other treatments), all at $5 \%$ of significance. For these analyses, the softwares Action (Equipe Estatcamp 2014), SOC (Embrapa 1997) and Sisvar 5.6 (Ferreira 2008) were used.

\section{RESULTS AND DISCUSSION}

The damage caused by S. frugiperda in maize plants was significantly reduced $(\mathrm{p}<0.01)$ by the presence of water inside the whorls at both experiments, especially at the early growth stages of the plants (Figure 2). The number of damaged plants was $17 \%$ lower when chlorantraniliprole was sprayed with water inside the whorls (Figures 2A and 2C). This effect was observed until the growth stage V8

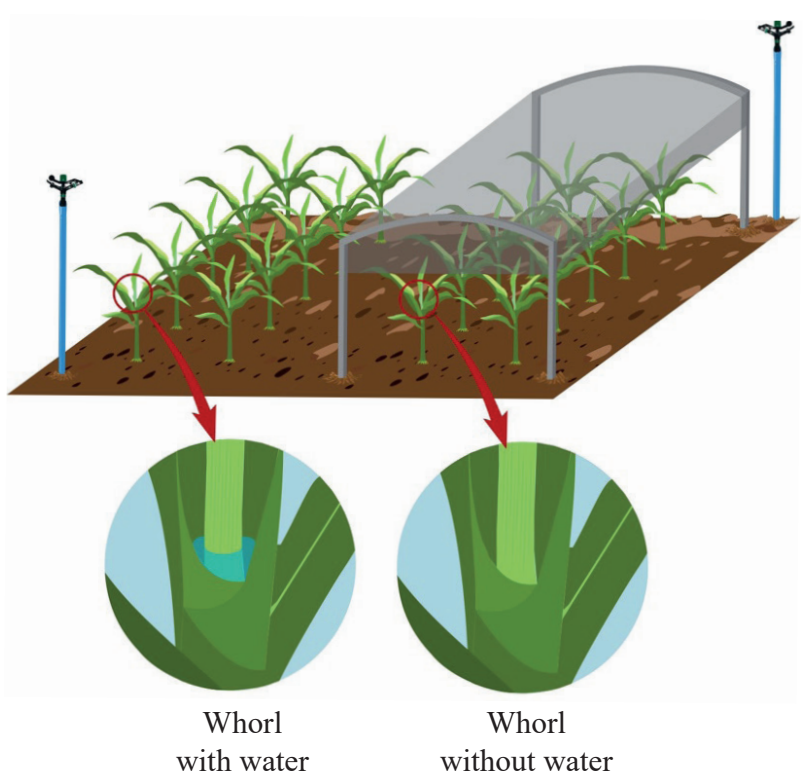

Figure 1. Depiction of the plots that received overhead irrigation (left) or remained sheltered by a plastic canvas (right). In detail, the storage of water inside the maize whorl after irrigation (4 mm). 

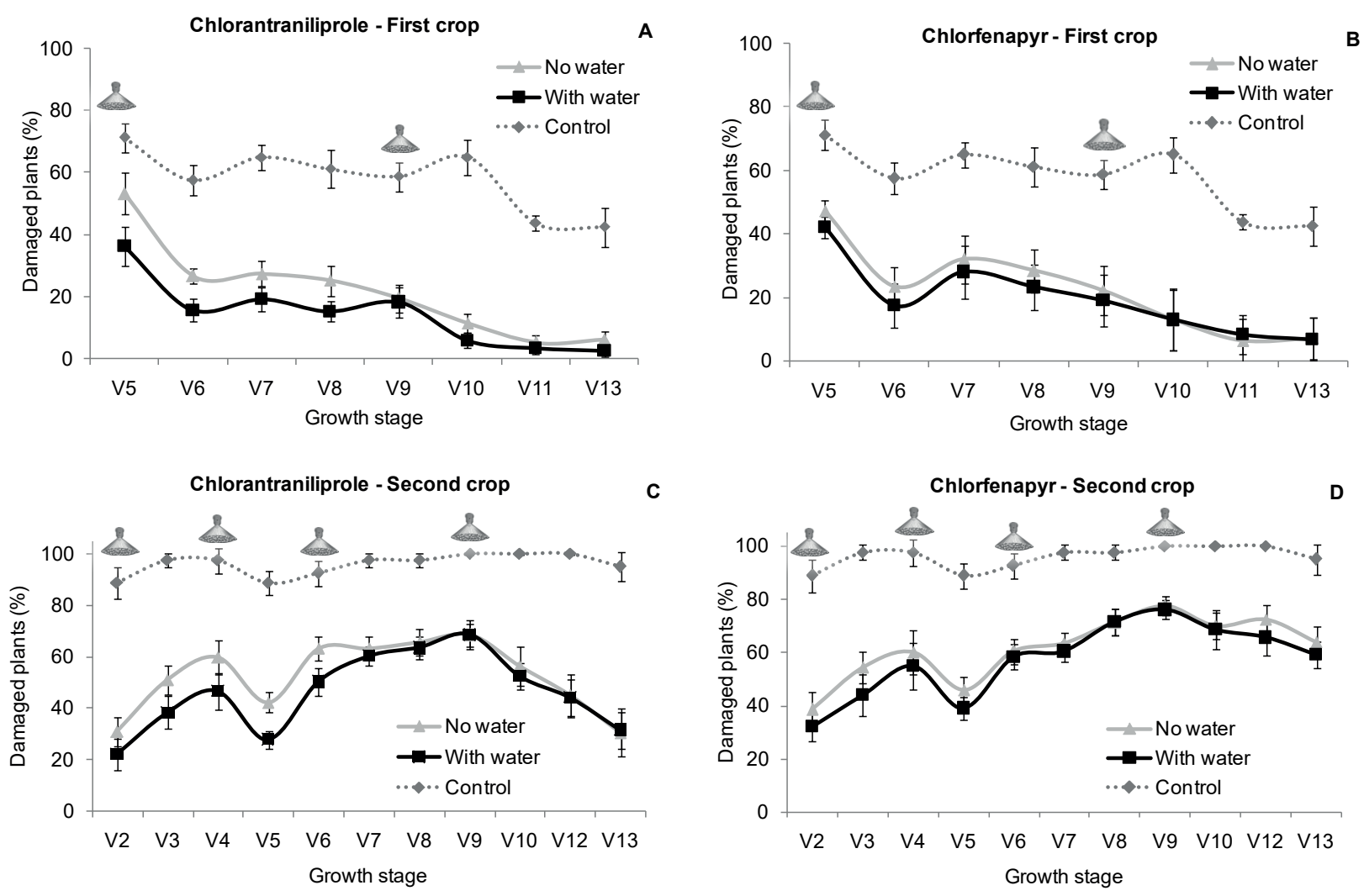

Figure 2. Number (mean \pm standard error) of maize plants damaged by Spodoptera frugiperda after spraying with chlorantraniliprole and chlorfenapyr, in the first (A, B) or second (C, D) crop, respectively. Lines represent damages associated to the treatments with no water inside the maize whorls, water inside the maize whorls and the untreated control; and spray jets over the lines indicate the moments of insecticide spray.

in the first crop, and until the stage V6 in the second. No significant reduction $(p>0.05)$ was obtained with the combination of chlorfenapyr and water inside the maize whorls, regardless of the plant growth stage and sowing date (Figures $2 \mathrm{~B}$ and $2 \mathrm{D}$ ).

The infestation by $S$. frugiperda was lower in the first crop, demanding only two insecticide sprays, against four in the second crop (at the growth stages V1, V4, V7 and V9, respectively). The occurrence of $S$. frugiperda in the Rio Grande do Sul state is higher in second-crop maize, demanding a high number of sprays to prevent economic damage in most maize hybrids (Farias 2014, Burtet et al. 2017). In this study, insecticide sprays were carried out fortnightly, or when the average of plant damage surpassed $20 \%$.

The damage caused by $S$. frugiperda has two distinct phases: significant difference between presence and absence of water during the early growth stages, and no significant difference during the late stages (Figure 2). Thus, data were grouped and analysed as early stages (V5 to V8) and late stages (V9 to V13) in the first crop, as well as early stages (V2 to V6) and late stages (V7 to V13) in the second crop. The factors spray set, insecticide and presence of water in the whorls differed significantly for the variables damaged plants and damage score at both experiments $(p<0.05)$ (Table 2), except for the variable damaged plants under presence of water inside the whorl in the second crop $(p=0.056)$. In both experiments, there was no interaction among water inside the whorls, insecticides and spray sets; however, the "water $\times$ insecticide" interaction showed a significant effect for damaged plants and damage score at the early stages of both crops, as well as the "insecticide $\times$ spray set" interaction for the late stage (Table 2).

The presence of water inside the maize whorls combined with chlorantraniliprole spray reduced significantly $(\mathrm{p}<0.05)$ the percentage of damaged plants and the damage scores of $S$. frugiperda at the early stage of both crops, regardless of spray set (Figure 3). In the first crop, the averages of 
Table 2. Summary of analyses of variance (p-values) for three variables ${ }^{1}$, as a function of the treatment factors (water inside the maize whorls, insecticides and spray sets), and their respective interactions, at two cropping seasons (different trials) and two development plant stages.

\begin{tabular}{|c|c|c|c|c|c|c|c|c|c|c|c|}
\hline \multirow{3}{*}{$\begin{array}{l}\text { Source of } \\
\text { variation }^{2}\end{array}$} & \multirow{3}{*}{ DF } & \multicolumn{5}{|c|}{ First crop } & \multicolumn{5}{|c|}{ Second crop } \\
\hline & & \multicolumn{2}{|c|}{ _ Early stages __ } & \multicolumn{2}{|c|}{ — Late stages _ } & \multirow{2}{*}{$\mathrm{Y}$} & \multicolumn{2}{|c|}{ _ Early stages _- } & \multicolumn{2}{|c|}{ _ Late stages _- } & \multirow{2}{*}{$\mathrm{Y}$} \\
\hline & & PD & D & PD & D & & PD & D & PD & D & \\
\hline Water (W) & 1 & $<0.001$ & $<0.001$ & 0.006 & 0.018 & 0.816 & $<0.001$ & $<0.001$ & 0.056 & $<0.001$ & 0.257 \\
\hline Insecticide (I) & 1 & $<0.001$ & $<0.001$ & $<0.001$ & $<0.001$ & 0.893 & $<0.001$ & $<0.001$ & $<0.001$ & $<0.001$ & 0.015 \\
\hline Spray set (S) & 4 & $<0.001$ & $<0.001$ & $<0.001$ & $<0.001$ & 0.146 & $<0.001$ & $<0.001$ & $<0.001$ & $<0.001$ & 0.369 \\
\hline $\mathrm{W} * \mathrm{I}$ & 1 & 0.001 & 0.038 & 0.045 & 0.053 & 0.960 & 0.001 & 0.012 & 0.430 & 0.608 & 0.713 \\
\hline $\mathrm{W} * \mathrm{~S}$ & 4 & 0.873 & 0.633 & 0.479 & 0.140 & 0.6 & 0.548 & 0.958 & 0.307 & 0.143 & 0.714 \\
\hline $\mathrm{I} * \mathrm{~S}$ & 4 & 0.996 & 0.839 & 0.001 & 0.004 & 0.903 & 0.369 & 0.833 & $<0.001$ & $<0.001$ & 0.626 \\
\hline $\mathrm{W} * \mathrm{I} * \mathrm{~S}$ & 4 & 0.428 & 0.928 & 0.863 & 0.811 & 0.244 & 0.687 & 0.817 & 0.195 & 0.481 & 0.799 \\
\hline UC vs. Factorial & 1 & $<0.001$ & $<0.001$ & $<0.001$ & $<0.001$ & $<0.001$ & $<0.001$ & $<0.001$ & $<0.001$ & $<0.001$ & $<0.001$ \\
\hline CV (\%) & - & 7.611 & 7.393 & 14.386 & 9.177 & 8.357 & 4.929 & 5.637 & 3.846 & 3.995 & 8.347 \\
\hline
\end{tabular}

${ }^{1} \mathrm{PD}$ : percentage of damaged maize plants by Spodoptera frugiperda; D: damage scores (Davis' scale); Y: grain yield. ${ }^{2}$ UC: untreated control (here in contrast with the other treatments, in a factorial scheme); CV: coefficient of variation; DF: degrees of freedom.

damaged plants and damage scores fell from $33.2 \%$ to $21.6 \%$ and from 0.6 to 0.4 , respectively; whereas, in the second crop, the reductions were of $49.4 \%$ to $37.0 \%$ and 2.6 to 1.9 . The most likely explanation for this control enhancement is that the presence of water inside the maize whorls (especially during the early growth stages of the crop; see Figure 1) forces the armyworm larvae to come out to perform a gas exchange through its spiracles, as observed during the conduction of the experiment. This behavior results in an increased exposure of the larvae to contamination with insecticide sprays, as well as to predation by natural enemies (e.g., insects, birds and pathogens).
As for the late stages, the water storage inside the maize whorls did not affect significantly the percentage of damaged plants. The $S$. frugiperda damage at late stages was lower in the first crop and higher in the second one (Figures 3 and 4). At this point of the crop cycle, armyworm larvae are well developed and protected by their excrements inside the maize whorls, hindering the control by chlorantraniliprole, even when combined with previous irrigation. Insecticide sprays during the early growth stages of the maize plants, on the other hand, may also lose the control efficiency due to the lower leaf area (Ceccon et al. 2004).

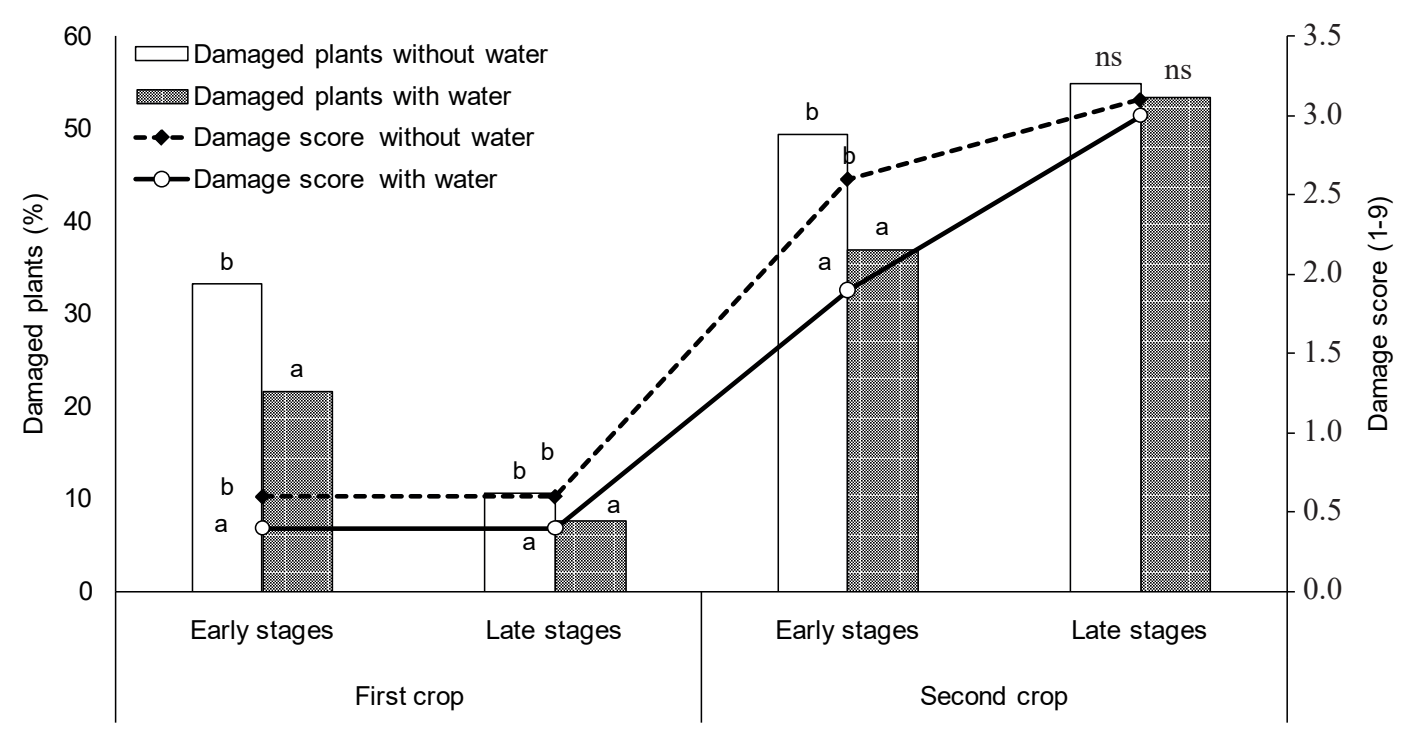

Figure 3. Effect of the water presence inside the maize whorls for the incidence and damage score of Spodoptera frugiperda on maize plants sprayed with chlorantraniliprole at two growing crops and two growth stages. Means followed by different letters in the columns are different by the F-test at $5 \%$ of probability; ns: non-significant. 


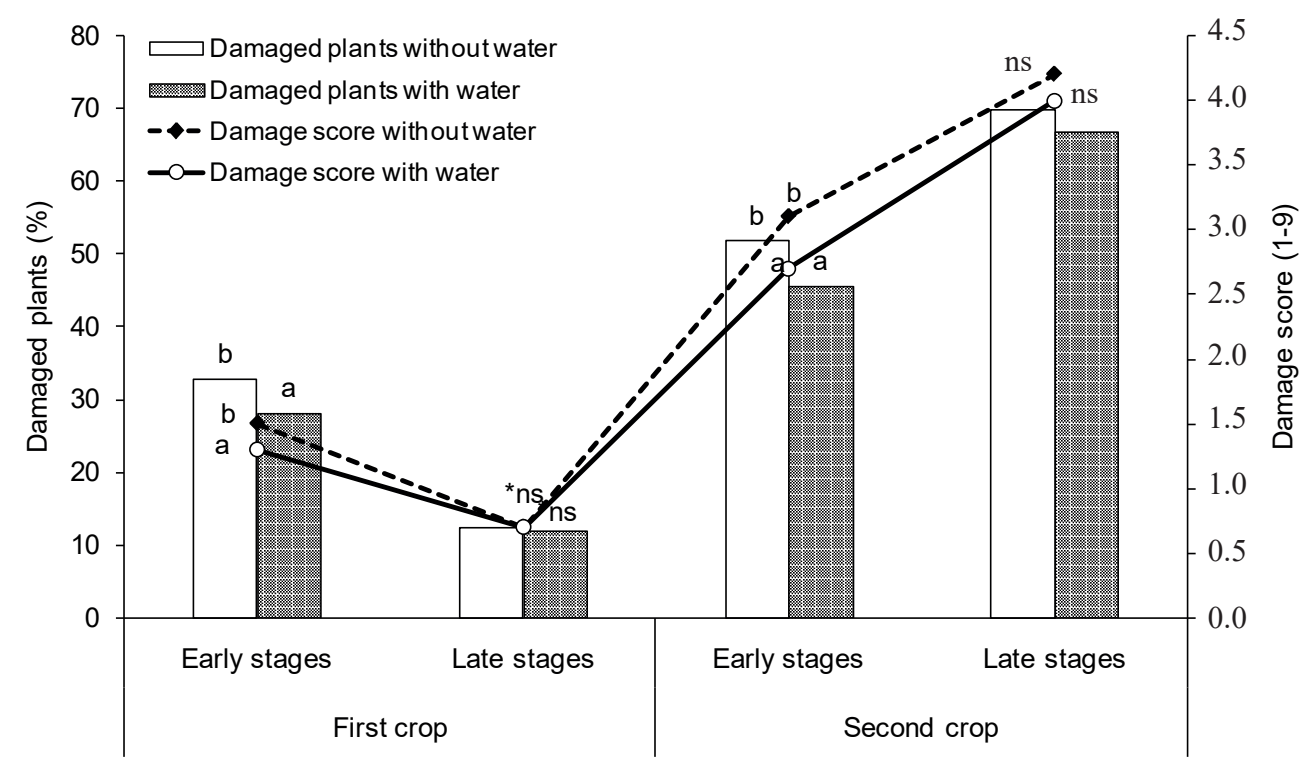

Figure 4. Effect of the water presence inside the maize whorls for the incidence and damage score of Spodoptera frugiperda on maize plants sprayed with chlorfenapyr at two growing crops and two growth stages. Means followed by different letters in the columns are different by the F-test at $5 \%$ of probability; ns: non-significant.

These results indicate that the water inside the maize whorls combined with chlorantraniliprole reduces in more than $10 \%$ the number of plants damaged by $S$. frugiperda during the early growth stages, regardless of spray set. Chlorantraniliprole is a ryanodine receptor modulator (IRAC 2019) widely regarded as highly efficient in the control of lepidopteran pests (Cordova et al. 2007). While control failures of $S$. frugiperda due to the selection of resistant strains have already been reported for many insecticides, in Brazil (e.g. spinosad, lambdacyhalothrin and lufenuron; see Diez-Rodríguez \& Omoto 2001, Okuma 2015 and Nascimento et al. 2016, respectively), the frequency of resistance alleles for chlorantraniliprole inside $S$. frugiperda populations seems to remain considerably low (Ribeiro 2014).

Increases in the spray volume, combined with the respective changes in the spray nozzle and pressure, enhanced the control of S. frugiperda with chlorantraniliprole in both crops. The spray set S4 (200 L ha-1 $; 20.3 \mathrm{psi}$ ) provided the lowest percentage of damaged plants and damage score, regardless of presence or absence of water inside the maize whorls (Table 3). The spray sets $\mathrm{S} 1$ (50 L ha-1; $12.3 \mathrm{psi}$ ) and S2 (100 $\left.\mathrm{L} \mathrm{ha}^{-1} ; 14.1 \mathrm{psi}\right)$ resulted in the highest damages, corroborating Silva (1999), which states low-volume sprays as one of the main factors leading to control failures of $S$. frugiperda in maize crops. The water inside the maize whorls significantly reduced the percentage of damaged plants at early stages (from $39.1 \%$ to $22.2 \%$ ), when combined with the spray sets S2, S3 and S4 (100 L ha- ${ }^{-1}, 150 \mathrm{~L} \mathrm{ha}^{-1}$ and $200 \mathrm{~L} \mathrm{ha}^{-1}$, respectively) in the first crop, and S3, S4 and S5 (150 L ha ${ }^{-1}, 200 \mathrm{~L} \mathrm{ha}^{-1}$ and $250 \mathrm{~L} \mathrm{ha}^{-1}$, respectively) in the second crop. However, no significant effect was observed at the late stages of both crops, since, at this development stages, the maize whorl has grown and can no longer store water inside.

During the early stages of the second crop and with absence of water inside the maize whorls, the percentage of damaged plants decreased to $41 \%$, when the spray volume was raised to $200 \mathrm{~L} \mathrm{ha}^{-1}$ (S4); after irrigation, however, the same percentage was obtained with half that volume (Table 3 ). Similar results were obtained at the early stages of the first crop. Thus, the presence of water inside the maize whorls at the early growth stages of the crop, whether from artificial irrigation or natural precipitation (e.g., rainfall, mist and dew), allows a reduction in the spray volume of chlorantraniliprole targeting at S. frugiperda. Lower spray volumes increase the operational efficiency by allowing the spraying of a bigger area in less time (Souza et al. 2012); however, the volume of reduction must be carefully pondered, in order to avoid control failures.

The damage by $S$. frugiperda was significantly reduced by chlorfenapyr, when combined with the 
Table 3. Means ${ }^{1}$ of damaged maize plants (\%) and damage scores (1 to 9) by Spodoptera frugiperda, at early and late plant growth stages, for combinations of the treatment factors water inside the maize whorls (no or with) and spray sets (S1 to S5) to the chlorantraniliprole insecticide.

\begin{tabular}{|c|c|c|c|c|c|c|c|c|c|c|}
\hline \multirow{2}{*}{ Treatments } & \multicolumn{5}{|c|}{ Early stages } & \multicolumn{5}{|c|}{ - Late stages } \\
\hline & $\mathrm{S} 1$ & $\mathrm{~S} 2$ & S3 & S4 & S5 & $\mathrm{S} 1$ & S2 & S3 & S4 & S5 \\
\hline & \multicolumn{10}{|c|}{ First crop - damaged plants (\%) } \\
\hline No water & $38.1 \mathrm{~A}$ & $39.1 \mathrm{Ab}$ & $32.2 \mathrm{Ab}$ & $27.8 \mathrm{Ab}$ & $28.8 \mathrm{~A}$ & $13.1 \mathrm{AB}$ & $15.6 \mathrm{~B}$ & $6.6 \mathrm{~A}$ & $6.9 \mathrm{~A}$ & $10.9 \mathrm{AB}$ \\
\hline With water & $29.4 \mathrm{~B}$ & $22.2 \mathrm{Aba}$ & $21.9 \mathrm{Aba}$ & $15.6 \mathrm{Aa}$ & $19.1 \mathrm{AB}$ & $12.2 \mathrm{~B}$ & $8.4 \mathrm{AB}$ & $4.4 \mathrm{~A}$ & $5.6 \mathrm{AB}$ & $7.2 \mathrm{AB}$ \\
\hline Mean & $33.8 \mathrm{C}$ & $30.6 \mathrm{BC}$ & $27.0 \mathrm{ABC}$ & $21.7 \mathrm{~A}$ & $23.9 \mathrm{AB}$ & $17.0 \mathrm{~B}$ & $12.0 \mathrm{~B}$ & $5.5 \mathrm{~A}$ & $6.3 \mathrm{~A}$ & $9.1 \mathrm{AB}$ \\
\hline \multirow[t]{2}{*}{ Control } & & & 63.8 & & & & & 52.5 & & \\
\hline & \multicolumn{10}{|c|}{ First crop - damage scores (1-9) } \\
\hline No water & $1.8^{\mathrm{ns}}$ & $1.7 \mathrm{~b}$ & 1.3 & 1.1 & 1.3 & $0.8 \mathrm{CB}$ & $1.0 \mathrm{Cb}$ & $0.3 \mathrm{~A}$ & $0.4 \mathrm{AB}$ & $0.6 \mathrm{ABC}$ \\
\hline With water & $1.3 \mathrm{~B}$ & $1.0 \mathrm{Aba}$ & $0.8 \mathrm{AB}$ & $0.6 \mathrm{~A}$ & $0.9 \mathrm{AB}$ & $0.7 \mathrm{~B}$ & $0.5 \mathrm{ABa}$ & $0.2 \mathrm{~A}$ & $0.3 \mathrm{~A}$ & $0.4 \mathrm{AB}$ \\
\hline Mean & $1.5 \mathrm{C}$ & $1.4 \mathrm{BC}$ & $1.1 \mathrm{AB}$ & $0.9 \mathrm{~A}$ & $1.1 \mathrm{AB}$ & $0.8 \mathrm{C}$ & $0.7 \mathrm{C}$ & $0.3 \mathrm{~A}$ & $0.3 \mathrm{~A}$ & $0.5 \mathrm{AB}$ \\
\hline \multirow[t]{2}{*}{ Control } & & & 3.5 & & & & & 3.4 & & \\
\hline & \multicolumn{10}{|c|}{ Second crop - damaged plants (\%) } \\
\hline No water & $62.0 \mathrm{~B}$ & $51.5 \mathrm{AB}$ & $47.8 \mathrm{Ab}$ & $41.0 \mathrm{Ab}$ & $44.8 \mathrm{Ab}$ & $71.3 \mathrm{D}$ & $62.1 \mathrm{CD}$ & $54.0 \mathrm{BC}$ & 44.6 AB & $42.7 \mathrm{~A}$ \\
\hline With water & $52.3 \mathrm{C}$ & $41.5 \mathrm{BC}$ & $32.5 \mathrm{ABa}$ & $28.3 \mathrm{Aa}$ & $30.3 \mathrm{Aa}$ & $62.3 \mathrm{~B}$ & $60.0 \mathrm{~B}$ & $51.0 \mathrm{AB}$ & $48.3 \mathrm{~A}$ & $45.2 \mathrm{~A}$ \\
\hline Mean & $57.1 \mathrm{C}$ & $46.5 \mathrm{~B}$ & $40.1 \mathrm{AB}$ & $34.6 \mathrm{~A}$ & $37.5 \mathrm{~A}$ & $66.8 \mathrm{C}$ & $61.0 \mathrm{BC}$ & $52.5 \mathrm{~B}$ & $46.5 \mathrm{~A}$ & $44.0 \mathrm{~A}$ \\
\hline \multirow[t]{2}{*}{ Control } & & & 93.0 & & & & & 98.3 & & \\
\hline & \multicolumn{10}{|c|}{ Second crop - damage scores (1-9) } \\
\hline No water & $3.5 \mathrm{~B}$ & $2.8 \mathrm{AB}$ & $2.5 \mathrm{ABb}$ & $2.1 \mathrm{Ab}$ & $2.3 \mathrm{Ab}$ & $4.2 \mathrm{C}$ & $3.7 \mathrm{BC}$ & $3.0 \mathrm{AB}$ & $2.5 \mathrm{~A}$ & $2.4 \mathrm{~A}$ \\
\hline With water & $2.8 \mathrm{~B}$ & $2.1 \mathrm{AB}$ & $1.7 \mathrm{Aa}$ & $1.5 \mathrm{Aa}$ & $1.5 \mathrm{Aa}$ & $3.5 \mathrm{~B}$ & $3.4 \mathrm{~B}$ & $2.8 \mathrm{AB}$ & $2.7 \mathrm{~A}$ & $2.5 \mathrm{~A}$ \\
\hline Mean & $3.1 \mathrm{C}$ & $2.5 \mathrm{~B}$ & $2.1 \mathrm{AB}$ & $1.8 \mathrm{~A}$ & $1.9 \mathrm{~A}$ & $3.8 \mathrm{C}$ & $3.5 \mathrm{BC}$ & $2.9 \mathrm{AB}$ & $2.6 \mathrm{AB}$ & $2.5 \mathrm{~A}$ \\
\hline Control & & & 6.3 & & & & & 7.2 & & \\
\hline
\end{tabular}

${ }^{1}$ Means followed by the same lowercase letter in the column and uppercase letter in the row are not significantly different by the Tukey test $(\mathrm{p}<0.05)$.

presence of water inside the maize whorls, at the early stages of both crops (Figures 2 and 4). The percentage of damaged plants decreased from $32.8 \%$ to $28.1 \%$ in the first crop and from $51.8 \%$ to $45.6 \%$ in the second one, showing that chlorfenapyr provides a lower control efficiency than chlorantraniliprole in these conditions. Similarly to the previous insecticide, the damage caused by S. frugiperda was not significantly affected during the late stages of the crop, regardless of water presence (Figure 4).

The low control efficiency provided by chlorfenapyr may be linked to intrinsic features of the product and the difficulty in reaching the target (i.e., $S$. frugiperda); however, the main reason is probably its low residual effect due to a rapid degradation in the environment (three to four days of half-life; Ditya et al. 2010). Chlorfenapyr is a pyrrole insecticide with a broad spectrum of action, activated by oxidative processes in metabolic enzymes of the insects (P450s, GSTs and COE) and functioning as an uncoupler of oxidative phosphorylation by disruption of the proton gradient (Hunt \& Treacy 1998, Feyereisen 2012). Considering that this insecticide is highly efficient in managing defoliating caterpillars of hard control (e.g., Chrysodeixis includens; Perini et al. 2019), the low control obtained for $S$. frugiperda in maize plants is likely related to the short availability of active ingredient for larvae contamination.

The presence of water inside the maize whorls did not significantly affect the results obtained for each spray set. The lowest means for damaged plants and damage scores were obtained with the spray sets S4 (200 L ha-1; 20.3 psi) and S5 (250 L ha ${ }^{-1} ; 33.4$ psi), regardless of sowing date and growth stage of the crop (Table 4). As observed for chlorantraniliprole, the spray sets with the lowest volumes (S1 and S2, with $50 \mathrm{~L} \mathrm{ha}^{-1}$ and $100 \mathrm{~L} \mathrm{ha}^{-1}$, respectively) resulted in the highest damages by $S$. frugiperda on maize plants.

The maize grain yield differed significantly $(p<0.01)$ between the untreated control and the treated groups for all factors (water inside the whorls, insecticides and spray sets) (Table 2). The yield reduction due to $S$. frugiperda attack in the control was estimated in more than $2,000 \mathrm{~kg} \mathrm{ha}^{-1}$, when compared with some of the treatments in the second crop (Table 5). The insecticide effect was significant $(p=0.015)$ only for the second growing crop (Table 2$)$, when the spraying with chlorantraniliprole resulted in an increase of $814.1 \mathrm{~kg} \mathrm{ha}^{-1}$, if compared to those with chlorfenapyr. For the conditions under which the 
Table 4. Means ${ }^{1}$ of damaged maize plants (\%) and damage scores (1 to 9) by Spodoptera frugiperda, at early and late plant growth stages, for combinations of the treatment factors water inside the maize whorls (no or with) and spray sets (S1 to S5) to the chlorfenapyr insecticide.

\begin{tabular}{|c|c|c|c|c|c|c|c|c|c|c|}
\hline \multirow{2}{*}{ Treatments } & \multicolumn{5}{|c|}{ Early stages } & \multicolumn{5}{|c|}{ - Late stages } \\
\hline & S1 & $\mathrm{S} 2$ & S3 & S4 & S5 & $\mathrm{S} 1$ & $\mathrm{~S} 2$ & S3 & S4 & S5 \\
\hline & \multicolumn{10}{|c|}{ First crop - damaged plants (\%) } \\
\hline No water & $41.9 \mathrm{~B}$ & $35.3 \mathrm{AB}$ & $32.5 \mathrm{AB}$ & $25.3 \mathrm{~A}$ & $29.1 \mathrm{~A}$ & $21.9 \mathrm{~B}$ & $14.1 \mathrm{AB}$ & $10.3 \mathrm{~A}$ & $7.5 \mathrm{~A}$ & $7.6 \mathrm{~A}$ \\
\hline With water & $34.4 \mathrm{~B}$ & $32.8 \mathrm{AB}$ & $27.2 \mathrm{AB}$ & $21.9 \mathrm{~A}$ & $24.4 \mathrm{AB}$ & $21.9 \mathrm{~B}$ & $12.8 \mathrm{AB}$ & $10.0 \mathrm{~A}$ & $7.2 \mathrm{~A}$ & $7.4 \mathrm{~A}$ \\
\hline Mean & $38.1 \mathrm{C}$ & $34.1 \mathrm{BC}$ & $29.8 \mathrm{AB}$ & $23.6 \mathrm{~A}$ & $26.7 \mathrm{AB}$ & $21.9 \mathrm{C}$ & $13.4 \mathrm{~B}$ & $10.2 \mathrm{AB}$ & $7.3 \mathrm{~A}$ & $7.5 \mathrm{~A}$ \\
\hline \multirow[t]{2}{*}{ Control } & & & 63.8 & & & & & 52.5 & & \\
\hline & \multicolumn{10}{|c|}{ First crop - damage scores (1-9) } \\
\hline No water & $2.0 \mathrm{~B}$ & $1.8 \mathrm{AB}$ & $1.4 \mathrm{AB}$ & $1.2 \mathrm{~A}$ & $1.3 \mathrm{AB}$ & $1.2 \mathrm{~B}$ & $0.9 \mathrm{AB}$ & $0.6 \mathrm{~A}$ & $0.4 \mathrm{~A}$ & $0.5 \mathrm{~A}$ \\
\hline With water & $1.7^{\mathrm{ns}}$ & 1.3 & 1.2 & 1.1 & 1.0 & $1.4 \mathrm{~B}$ & $0.7 \mathrm{~A}$ & $0.6 \mathrm{~A}$ & $0.4 \mathrm{~A}$ & $0.5 \mathrm{~A}$ \\
\hline Mean & $1.9 \mathrm{C}$ & $1.5 \mathrm{BC}$ & $1.3 \mathrm{AB}$ & $1.1 \mathrm{~A}$ & $1.2 \mathrm{AB}$ & $1.3 \mathrm{C}$ & $0.8 \mathrm{~B}$ & $0.6 \mathrm{AB}$ & $0.4 \mathrm{~A}$ & $0.5 \mathrm{~A}$ \\
\hline \multirow[t]{2}{*}{ Control } & & & 3.5 & & & & & 3.4 & & \\
\hline & \multicolumn{10}{|c|}{ Second crop - damaged plants (\%) } \\
\hline No water & $67.0 \mathrm{C}$ & $55.8 \mathrm{BC}$ & $49.5 \mathrm{AB}$ & $45.3 \mathrm{AB}$ & $41.3 \mathrm{~A}$ & $80.8 \mathrm{~B}$ & $69.6 \mathrm{AB}$ & $67.7 \mathrm{AB}$ & $61.7 \mathrm{~A}$ & $69.2 \mathrm{AB}$ \\
\hline With water & $60.8 \mathrm{C}$ & $49.5 \mathrm{BC}$ & $43.8 \mathrm{AB}$ & $37.8 \mathrm{~A}$ & $36.3 \mathrm{~A}$ & $80.0 \mathrm{~B}$ & $66.3 \mathrm{~A}$ & $62.3 \mathrm{~A}$ & $60.2 \mathrm{~A}$ & $65.2 \mathrm{~A}$ \\
\hline Mean & $63.9 \mathrm{D}$ & $52.6 \mathrm{C}$ & $46.6 \mathrm{BC}$ & $41.5 \mathrm{AB}$ & $38.8 \mathrm{~A}$ & $80.4 \mathrm{~B}$ & $67.9 \mathrm{~A}$ & $65.0 \mathrm{~A}$ & $60.9 \mathrm{~A}$ & $67.2 \mathrm{~A}$ \\
\hline \multirow[t]{2}{*}{ Control } & & & 93.0 & & & & & 98.3 & & \\
\hline & \multicolumn{10}{|c|}{ Second crop - damage scores (1-9) } \\
\hline No water & $4.2 \mathrm{~B}$ & $3.3 \mathrm{AB}$ & $2.9 \mathrm{~A}$ & $2.7 \mathrm{~A}$ & $2.4 \mathrm{~A}$ & $5.1 \mathrm{~B}$ & $4.2 \mathrm{AB}$ & 4.0 AB & $3.6 \mathrm{~A}$ & $4.2 \mathrm{~A}$ \\
\hline With water & $3.6 \mathrm{~B}$ & $2.9 \mathrm{AB}$ & $2.5 \mathrm{~A}$ & $2.2 \mathrm{~A}$ & $2.1 \mathrm{~A}$ & $4.8 \mathrm{~B}$ & $3.8 \mathrm{AB}$ & $3.7 \mathrm{~A}$ & $3.6 \mathrm{~A}$ & $3.9 \mathrm{~A}$ \\
\hline Mean & $3.9 \mathrm{C}$ & $3.1 \mathrm{~B}$ & $2.7 \mathrm{AB}$ & $2.5 \mathrm{~A}$ & $2.2 \mathrm{~A}$ & $4.9 \mathrm{C}$ & $4.0 \mathrm{~B}$ & $3.8 \mathrm{AB}$ & $3.6 \mathrm{~A}$ & $4.1 \mathrm{~A}$ \\
\hline Control & & & 6.3 & & & & & 7.2 & & \\
\hline
\end{tabular}

${ }^{1}$ Means followed by the same lowercase letter in the column and uppercase letter in the row are not significantly different by the Tukey test ( $\mathrm{p}<0.05$ ).

Table 5. Means ${ }^{1}$ of maize grain yield $\left(\mathrm{kg} \mathrm{ha}^{1}\right)$ in response to combinations of the treatment factors water inside the whorls (no or with), spray sets (S1 to S5) and insecticide (chlorantraniliprole or chlorfenapyr) used for the damage control of Spodoptera frugiperda.

\begin{tabular}{|c|c|c|c|c|c|c|c|c|c|c|}
\hline \multirow{2}{*}{ Treatments } & \multicolumn{5}{|c|}{ First crop } & \multicolumn{5}{|c|}{ Second crop } \\
\hline & S1 & S2 & S3 & $\mathrm{S} 4$ & S5 & $\mathrm{S} 1$ & S2 & $\mathrm{S} 3$ & S4 & S5 \\
\hline & \multicolumn{10}{|c|}{ Chlorantraniliprole } \\
\hline No water & $4,007.3$ & $3,701.2$ & $4,378.5$ & $4,107.6$ & $4,354.1$ & $4,858.6$ & $5,155.3$ & $5,558.5$ & $5,426.1$ & $5,711.9$ \\
\hline With water & $4,140.1$ & $4,703.7$ & $4,608.8$ & $4,400.2$ & $4,760.6$ & $5,319.9$ & $5,049.8$ & $5,889.0$ & $5,697.6$ & $5,855.8$ \\
\hline Mean & $4,073.7$ & $4,202.4$ & $4,493.7$ & $4,253.9$ & $4,557.4$ & $5,089.3$ & $5,102.5$ & $5,723.8$ & $5,561.9$ & $5,783.8$ \\
\hline \multirow[t]{2}{*}{ Control } & & & $3,300.2$ & & & & & $3,389.5$ & & \\
\hline & \multicolumn{10}{|c|}{ Chlorfenapyr } \\
\hline No water & $4,115.7$ & $4,183.4$ & $4,568.2$ & $4,310.8$ & $4,649.5$ & $4,619.6$ & $4,908.1$ & $4,490.1$ & $5,237.4$ & $5,018.0$ \\
\hline With water & $4,072.4$ & $4,486.9$ & $4,741.6$ & $4,619.7$ & $4,497.7$ & $4,710.0$ & $5,416.3$ & $5,132.9$ & $5,187.1$ & $5,037.0$ \\
\hline Mean & $4,094.0$ & $4,335.2$ & $4,654.9$ & $4,465.2$ & $4,573.6$ & $4,664.8$ & $5,162.2$ & $4,811.5$ & $5,212.3$ & $5,027.5$ \\
\hline Control & & & $3,300.2$ & & & & & $3,389.5$ & & \\
\hline
\end{tabular}

${ }^{1}$ Means of treatments "with water" and "no water" for each spray set are non-significant ( $\left.>0.05\right)$ by the Tukey test.

experiments were carried out, the means obtained for all treatments stayed below the average maize yield of the Rio Grande do Sul state $\left(6,164 \mathrm{~kg} \mathrm{ha}^{-1}\right.$; Conab 2016). These results are probably associated with a period of low rainfall, which coincided with the reproductive phase of the plants, the most vulnerable stage of the maize development cycle (Magalhães \& Durães 2006).
Overall, the increased control rates obtained in both experiments do not justify the costs of irrigating the crop prior to insecticide spraying, solely to that end. However, when the plant demand for water coincides with the need for insecticide application, the two operations can be combined without further costs to increase the control of S. frugiperda. Additionally, when natural water accumulates inside the maize whorls 
(from rainfall or dew), the control can be increased by simply adjusting the timing of spray (moving it to early morning, for instance), or optimizing the workflow by reducing the spray volume. This alternative is especially relevant if considering that many maize growers in southern Brazil are smallholder farmers who cannot afford irrigation systems.

\section{CONCLUSION}

Insecticide sprays combined with water inside the maize whorls reduce the damages caused by $S$. frugiperda at early plant growth stages. This effect is more effective for chlorantraniliprole, in comparison with chlorfenapyr. The spray sets with $200 \mathrm{~L} \mathrm{ha}^{-1 / 20.3}$ psi or $250 \mathrm{~L} \mathrm{ha}^{-1 / 33.4}$ psi result in low damages by $S$. frupiperda in maize plants. The presence of water inside the maize whorls, whether from irrigation, dew or rainfall, enhances the control efficiency of chlorantraniliprole and chlorfenapyr to $S$. frugiperda in maize crops, especially for the $B t$-maize studied here.

\section{REFERENCES}

ALVARES, C. A.; STAPE, J. L.; SENTELHAS, P. C.; GONÇALVES, J. L. M.; SPAROVEK, G. Köppen's climate classification map for Brazil. Meteorologische Zeitschrift, v. 22, n. 6, p. 711-728, 2013.

BASANTA, M. V.; DOURADO-NETO, D.; GARCÍA, A. G. Estimativa do volume máximo de calda para aplicação foliar de produtos químicos na cultura de milho. Scientia Agricola, v. 57, n. 2, p. 283-288, 2000.

BAYER, T.; COSTA, I. F. D.; LENZ, G.; ZEMOLIN, C.; MARQUES, L. N.; STEFANELO, M. S. Equipamentos de pulverização aérea e taxas de aplicação de fungicida na cultura do arroz irrigado. Revista Brasileira de Engenharia Agrícola e Ambiental, v. 15, n. 2, p. 192-198, 2011.

BURTET, L. M.; BERNARDI, O.; MELO, A. A.; PES, M. P.; STRAHL, T. T.; GUEDES, J. V. C. Managing fall armyworm, Spodoptera frugiperda (Lepidoptera: Noctuidae), with Bt maize and insecticides in southern Brazil. Pest Management Science, v. 73, n. 12, p. 25692577, 2017.

BUSATO, G. R.; GRUTZMACHER, A. D.; GARCIA, M. S. Consumption and utilization of food by Spodoptera frugiperda (J. E. Smith) (Lepidoptera: Noctuidae) native to different areas in Rio Grande do Sul, from corn and irrigated rice. Neotropical Entomology, v. 31, n. 4, p. 525529, 2002.
CECCON, G.; RAGA, A.; DUARTE, A. P.; SILOTO, R. C. Efeito de inseticidas na semeadura sobre pragas iniciais e produtividade de milho safrinha em plantio direto. Bragantia, v. 63, n. 2, p. 227-237, 2004.

COMPANHIA NACIONAL DE ABASTECIMENTO (Conab). Ministério da Agricultura, Pecuária e Abastecimento. Acompanhamento de safra brasileira: grãos: primeiro levantamento: safra 2016/17. Brasília, DF: Conab, 2016.

CORDOVA, D.; BENNER, E. A.; SACHER, M. D.; RAUH, J. J.; SOPA, J. S.; LAHM, G. P.; SELBY, T. P.; STEVENSON, T. M.; FLEXNER, L.; GUTTERIDGE, S.; RHOADES, D. F.; WU, L.; SMITH, R. M.; TAO, Y. The novel mode of action of anthranilic diamide insecticides: ryanodine receptor activation. In: LYGA, J. W.; THEODORITIS, G. Synthesis and chemistry of agrochemicals VII. Washington, DC: American Chemical Society, 2007. p. 223-234.

CRUZ, J. C.; KARAM, D.; MONTEIRO, M. A. R.; MAGALHÃES, P. C. A cultura do milho. Sete Lagoas: Embrapa Milho e Sorgo, 2008.

CRUZ, J. C.; PEREIRA FILHO, I. A.; QUEIROZ, L. R. Quatrocentas e sessenta e sete cultivares de milho estão disponiveis no mercado de sementes do Brasil para a safra 2012/13. Sete Lagoas: Embrapa Milho e Sorgo, 2013.

DAVIS, F. M.; NG, S. S.; WILLIAMS, W. P. Visual rating scales for screening whorl-stage corn for resistance to fall armyworm. Starkville: Mississippi Agricultural and Forest Experiment Station, 1992.

DIEZ-RODRÍGUEZ, G. I.; OMOTO, C. Inheritance of lambda-cyhalothrin resistance in Spodoptera frugiperda (J. E. Smith) (Lepidoptera: Noctuidae). Neotropical Entomology, v. 30, n. 2, p. 311-316, 2001.

DITYA, P.; DAS, S. P.; SARKAR, P. K.; BHATTACHARYYA, A. Degradation dynamics of chlorfenapyr residue in chili, cabbage and soil. Bulletin of Environmental Contamination and Toxicology, v. 84, n. 5, p. 602-605, 2010.

EMPRESA BRASILEIRA DE PESQUISA AGROPECUÁRIA (Embrapa). SOC: ambiente de software NTIA, versão 4.2.2: manual do usuário: ferramental estatístico. Campinas: Embrapa, 1997.

EQUIPE ESTATCAMP. Software action. 2014. Disponível em: http://www.portalaction.com.br/. Acesso em: 15 mar. 2018.

FARIAS, J. R.; ANDOW, D. A.; HORIKOSHI, R. J.; SORGATTO, R. J.; FRESIA, P.; SANTOS, A. C. dos; OMOTO, C. Field-evolved resistance to Cry1F maize by Spodoptera frugiperda (Lepidoptera: Noctuidae) in Brazil. Crop Protection, v. 64, n. 2, p. 150-158, 2014. 
FERREIRA, D. F. Sisvar: um programa para análises e ensino de estatística. Revista Simposium, v. 6, n. 2, p. 3641, 2008 .

FEYEREISEN, R. Insect CYP genes and P450 enzymes. In: GILBERT, L. I. (ed.). Insect molecular biology and biochemistry. Oxford: Academic Press, 2012. p. 236316.

GASSEN, D. N. Manejo de pragas associadas à cultura do milho. Passo Fundo: Aldeia Norte, 1996.

GIRARDIN, P. The funnel effect of a maize canopy. In: CONGRESS OF THE EUROPEAN SOCIETY FOR AGRONOMY, 2., 1992, Wellesbourne. Proceedings... Wellesbourne: Warwick University, 1992. p. 76-77.

GUEDES, J. V. C.; MAZIERO, H. Tecnologia de aplicação de inseticidas. In: ANTUNIASSI, U. R.; BOLLER, W. (ed.). Tecnologia de aplicação para culturas anuais. Passo Fundo: Aldeia Norte, 2011. p. 241-251.

HUNT, D. A.; TREACY, M. F. Pyrrole insecticides: a new class of agriculturally important insecticides functioning as uncouplers of oxidative phosphorylation. In: ISHAAYA, I.; DEGHEELE, D. (ed.). Insecticides with novel modes of action: mechanism and application. Berlin: Springer, 1998. p. 138-139.

INSECTICIDE RESISTANCE ACTION COMMITTEE (IRAC). IRAC mode of action classification scheme. 2019. Disponível em: https://www.irac-online.org/documents/ moa-structures-poster-english/?ext=pdf. Acesso em: 29 abr. 2019.

INSECTICIDE RESISTANCE ACTION COMMITTEE (IRAC). Recomendações de manejo da resistência a inseticidas e manejo de pragas para soja, algodão e milho no Brasil. 2017. Disponível em: http://media.wix.com/ ugd/2bed6c_52f993a9b3ed4c548138d3fbf81c283c.pdf. Acesso em: 10 jun. 2018.

MAGALHÃES, P. C.; DURÃES, F. O. M. Fisiologia da produção do milho. Sete Lagoas: Embrapa, 2006.
NASCIMENTO, A. R. B.; FARIAS, J. R.; BERNARDI, D.; HORIKOSHI, R. J.; OMOTO, C. Genetic basis of Spodoptera frugiperda (Lepidoptera: Noctuidae) resistance to the chitin synthesis inhibitor lufenuron. Pest Management Science, v. 72, n. 4, p. 810-815, 2016.

OKUMA, D. M. Genetic and molecular basis of Spodoptera frugiperda (J. E. Smith) (Lepidoptera: Noctuidae) resistance to spinosad. 2015. Dissertação (Mestrado em Entomologia) - Escola Superior de Agricultura Luiz de Queiroz, Piracicaba, 2015.

PERINI, C. R.; ARNEMANN, J. A.; CAVALLIN, L. A.; GUEDES, G. A.; MARQUES, R. P.; VALMORBIDA, I.; SILVA, K.; FELTRIN, N. M.; PUNTEL, L.; FROEHLICH, R.; GUEDES, J. V. C. Challenges in Chrysodeixis includens management with chemical insecticides trigger to high control costs in Brazil. Australian Journal of Crop Science, v. 13, n. 10, p. 1723-1730, 2019.

RIBEIRO, R.S. Monitoring the susceptibility to diamide insecticides in Spodoptera frugiperda (J. E. Smith) (Lepidoptera: Noctuidae) populations in Brazil. 2014. Dissertação (Mestrado em Entomologia) - Escola Superior de Agricultura Luiz de Queiroz, Piracicaba, 2014.

RITCHIE, S. W.; HANWAY, J. J.; BENSON, G. O. How a corn plant develops? Ames: Iowa State University of Science and Technology, 1993.

SILVA, M. T. B. Fatores que afetam a eficiência de inseticidas sobre Spodoptera frugiperda Smith em milho. Ciência Rural, v. 29, n. 3, p. 383-387, 1999.

SOUZA, L. A.; CUNHA, J. P. R. A.; PAVANIN, L. A. Deposição do herbicida 2,4-D amina com diferentes volumes e pontas de pulverização em plantas infestantes. Revista Ciência Agronômica, v. 43, n. 1, p. 78-85, 2012.

VIEIRA, R. F.; SILVA, A. A. Aplicação de defensivos via água de irrigação por aspersão. In: VIEIRA, C.; PAULA JÚNIOR, T. J.; BORÉM, A. (ed.). Feijão. Viçosa: Ed. UFV, 2006. p. 259-308. 